\title{
Globalisation, the global village and the civil society
}

Citation for published version (APA):

Martens, P., Dreher, A., \& Gaston, N. (2010). Globalisation, the global village and the civil society. Futures, 42(6), 574-582. https://doi.org/10.1016/j.futures.2010.01.008

Document status and date:

Published: 01/08/2010

DOI:

10.1016/j.futures.2010.01.008

Document Version:

Publisher's PDF, also known as Version of record

Document license:

Taverne

Please check the document version of this publication:

- A submitted manuscript is the version of the article upon submission and before peer-review. There can be important differences between the submitted version and the official published version of record.

People interested in the research are advised to contact the author for the final version of the publication, or visit the DOI to the publisher's website.

- The final author version and the galley proof are versions of the publication after peer review.

- The final published version features the final layout of the paper including the volume, issue and page numbers.

Link to publication

\footnotetext{
General rights rights.

- You may freely distribute the URL identifying the publication in the public portal. please follow below link for the End User Agreement:

www.umlib.nl/taverne-license

Take down policy

If you believe that this document breaches copyright please contact us at:

repository@maastrichtuniversity.nl

providing details and we will investigate your claim.
}

Copyright and moral rights for the publications made accessible in the public portal are retained by the authors and/or other copyright owners and it is a condition of accessing publications that users recognise and abide by the legal requirements associated with these

- Users may download and print one copy of any publication from the public portal for the purpose of private study or research.

- You may not further distribute the material or use it for any profit-making activity or commercial gain

If the publication is distributed under the terms of Article $25 \mathrm{fa}$ of the Dutch Copyright Act, indicated by the "Taverne" license above, 


\title{
Globalisation, the global village and the civil society
}

\author{
Pim Martens ${ }^{\mathrm{a}, *}$, Axel Dreher ${ }^{\mathrm{b}}$, Noel Gaston ${ }^{\mathrm{c}}$ \\ ${ }^{a}$ International Centre for Integrated Assessment and Sustainable Development (ICIS), Maastricht University, Maastricht, The Netherlands \\ ${ }^{\mathrm{b}}$ Georg-August University Goettingen, Goettingen, Germany \\ ${ }^{\mathrm{c}}$ Globalisation and Development Centre, Bond University, Gold Coast, Queensland, Australia
}

\section{A R T I C L E I N F O}

\section{Article history:}

Available online 25 January 2010

\begin{abstract}
A B S T R A C T
Human dynamics, institutional change, political relations and the global environment have become increasingly intertwined. The development of multicultural societies has certainly not been without its problems. The re-emergence of extremist political parties, the segregation of cultures and ethnic conflict, illustrate the problematic side of sociocultural integration at the local level. We argue that socio-cultural factors not only change as a result of globalisation, but also can be causes, as well as challenges to the process of globalisation itself. We describe how the recent introduction of the MGI and KOF globalisation indices can be used to empirically address to what extent globalisation affects social phenomena. Overall, while the rigidity of national boarders slackens, to speak about a global community is misleading. National borders still exist and the nationstate still matters. The fact is that they have to co-exist with civil society. The institutions of global civil society place limits upon the government and function as a sort of check on various forms of government, especially the authoritarian and absolutist varieties.
\end{abstract}

(c) 2010 Elsevier Ltd. All rights reserved.

\section{Introduction}

During the last few decades, human dynamics, institutional change, political relations and the global environment have become successively more intertwined. While increased global economic integration, global forms of governance, globally inter-linked social and environmental developments are often referred to as globalisation, there is no unanimously agreed upon definition of globalisation. It means different things to different people. Depending on the researcher or commentator, it can mean the growing integration of markets and nation-states and the spread of technological advancements [18]; receding geographical constraints on social and cultural arrangements [53]; the increased dissemination of ideas and technologies [1]; the threat to national sovereignty by transnational actors [2]; or the transformation of the economic, political and cultural foundations of societies [36]. Scholte [49] argues for the globalisation concept moving beyond being a buzzword for almost anything that is vaguely associated with it. Otherwise, discourse on globalisation runs the risk of being brushed aside as being “... 'globaloney', 'global babble' and 'glob-blah-blah”'.

If things were not sufficiently confusing, there has also been a spawning of preferred terms and descriptors. Keohane and Nye [29] distinguish between globalisation and globalism, where the former term refers to the process by which globalism, i.e., "the networks of interdependence at multicontinental distances", is altered. The concept of internationalisation is also highly significant (see, e.g., $[48,10,24]$ ). It refers to the role of the nation-state, often in cooperation and interaction with other nation-states, in adapting to global challenges. In contrast, globalisation is often thought to be a direct threat to the existence of the nation-state itself. So, by and large, internationalisation is best thought of as the response to globalisation.

\footnotetext{
* Corresponding author.

E-mail address: p.martens@maastrichtuniversity.nl (P. Martens).
} 
The world increasingly shares problems and challenges that are not confined within national boundaries. Multi-regional financial crises, world-wide pandemics and cross-border pollution are obvious examples. Such problems place the spotlight on the world's most prominent supra-national organisations - the United Nations (UN), the World Bank, the World Trade Organization (WTO) and the International Monetary Fund (IMF). Citizens' interests and welfare are increasingly being affected and, according to some, undermined by these bodies. If true, not only might such a development threaten representative democracy, but also it potentially abrogates the role of the nation-state itself.

It is also clear that globalisation is something more than a purely economic phenomenon manifesting itself on a global scale. Friedman [18] associates modern-day globalisation with Americanisation (or more pointedly, U.S.-isation). And, after all, shouldn't everyone just flow with the times and spell globalisation with a ' $z$ '!? Fiss and Hirsch [16] analyse full-text datasets of newspaper articles and press releases related to globalisation and show that the globalisation discourse emerged as a response to greater U.S. involvement in the international economy. Between 1985 and 1998, the use of the term "globalisation" increased substantially. The authors argue that the term originates in the early 1970s, with little consensus of what it means or how it should be defined. Politically, socially and culturally, globalisation is thought to erode national cultures due to the pervasiveness of the global media and the information and communication technologies (ICT) revolution. The economic dimensions of globalisation have an impact. The flows of goods and services and factors of production - labour and capital - have both direct and indirect effects on the nation-state [19]. With respect to the latter, national policies are affected - internationalisation, recall - and the economic, political and socio-cultural fabric of societies is fundamentally altered.

Among the more visible manifestations of globalisation are the greater international movement of goods and services, financial capital, information and people. In addition, there are technological developments, new and enhanced legal systems and institutions that facilitate these flows. On the cultural front, there are more international cultural exchanges, the spread of multi-culturalism and greater cultural diversity within many countries. Such developments are facilitated by the freer trade of more differentiated products as well as by tourism and immigration. Flows of immigration - both legal and illegal - also contribute to today's melting pot societies.

For many commentators, particularly economists, there is little doubt that globalisation has produced significant gains at the global level [4]. Foreign trade in goods and services, capital, technology and labour all move more freely across borders. In addition to economic gains, there have been significant benefits in the areas of culture and governance [15]. Public awareness of issues such as human rights, democracy and gender equality has increased significantly because of the greater access to newspapers, radio, television, telephones, computers and the internet. These developments have arguably led to improved allocative efficiency that, in turn, enhances growth and human development [52].

At the same time, globalisation is also perceived as creating new threats: to individuals, societies and eco-systems. There are fears that it may exacerbate the gap between rich and poor - both within and across countries - creating new threats to human security in terms of financial volatility, political and cultural insecurity and environmental degradation. In other words, the beneficial, innovative and dynamic aspects of globalisation are being tempered, and according to some, more than offset by forces that create disruption and marginalisation, such as population growth and migration, the emergence of infectious diseases, widening disparities in development world-wide, climate change, an accelerating loss of bio-diversity and the scarcity and pollution of fresh-water resources.

The subject of fierce debate, protests and occasional violent confrontations, modern globalisation is a lightening rod for both its supporters and detractors. The massive protests against globalisation were highly visible at the WTO summit in Seattle in December 1999. Seattle became a launch pad for further protests whenever the WTO, World Bank, the Group of Eight (G-8) or multinationals convened, e.g., at Quebec, Geneva, Göteborg and Genoa. Although the anti-globalisation activists were initially portrayed as a bunch of 'spoiled brats', there has been a growing acceptance that the protest movement is heterogeneous. It consists of various groups of people that do not all share the same vision. Some oppose globalisation in its current form because it is seen as predominantly capitalist in nature. Others see it as a threat to national sovereignty. Other groups do not oppose capitalism per se, but criticise the inability to more equitably distribute the benefits of globalisation.

The delicate balance between the costs and benefits of greater global integration and reduced geographic isolation is illustrated by the temptation to closely associate contemporary globalisation with the growth of terrorism. Terrorist attacks more often take place in foreign countries that are geographically, culturally, socially and politically distinct from the terrorists' own countries. On the other hand, the least globalised countries seem to suffer the worst of the most significant terror attacks [17]. This is but one of many issues, which seem so closely linked with the process of globalisation.

\section{The global village}

The late 1960s witnessed remarkable socio-cultural changes. The rise of the flower power generation, anti-Vietnam protests, the sexual revolution, and movements for the emancipation of women, non-whites, homosexuals and other "minorities" represent only the tip of the iceberg. For example, the emergence of pop art also marked the change to a postmodern culture [23]. Moreover, the publication of Marshall McLuhan's The Medium is the Massage in 1967, in which the world is described as becoming a 'global village', is one of the first socio-cultural landmarks that points at the existence of globalisation. Considering these circumstances, it is impossible to regard globalisation as purely an economic, political or technological phenomenon. 
The increased influence of the media on our daily lives has not only changed our way of perceiving the world and our consumption patterns, it has also affected local cultures. In the view of the cultural pessimists, the United States (particularly Hollywood) has established a global culture, arguably at the cost of traditional and local ones [7]. Youth the world over have especially embraced this culture, emphasising the freedom of choice that this global culture often advocates.

The introduction of the television in the 1950s, for example, had a profound impact on people's daily lives. Moreover, the growth of ICT has also influenced a lot of people's lives with its introduction of e-mail, chat rooms and blogging. As long as the technological facilities are available, personal communication between individuals is possible, regardless of the distance separating them. However, the world has not only become practicably smaller - new spaces, such as the internet, have simultaneously shaped a new dimension in our lives. Castells [9] refers to the present era as the information age. The emergence of the information super-highway and international and global media networks such as BBC-World, CNN and AlJazeera, as well as national and local media connected to global media networks, provide us daily with news from all over the globe [28]. The world is increasingly becoming a global village because people's lives - irrespective of their specific locationare connected with other parts of the world through the media. The news of oppressed Afghan women in burkas does not leave us unaffected. Less than 60 years ago the average citizen may barely have known that Afghanistan existed.

At the local level, globalisation has not led just to what some commentators argue to be an 'Americanisation' of traditional cultures. It has also increased interpersonal international cultural exchanges via migration, tourism and exchange studentship. Many homogeneous societies have been transformed into multicultural communities in which people from different cultural backgrounds and ethnicities live together.

The development of multicultural societies has certainly not been without its problems or its detractors [5]. The unsettling re-emergence of extremist political parties, the segregation of cultures and even ethnic riots, illustrate the problematic side of socio-cultural integration at the local level. In a world in which financial capital and many goods are moved freely from one country to another, the tightening of immigration laws seems to be 'deglobalising'. Socio-cultural factors therefore not only change as a result of globalisation, they can be causes, as well as challenges to the process of globalisation itself.

\section{The civil society}

Another concept influenced by globalisation (and in turn shaping globalisation) is the 'civil society'. Whether we speak about a rebirth or a rise of 'civil society', it is quite apparent that it is central to the contemporary political discourse. Civil society, in a purely descriptive sense, refers purely to those social movements that operate across borders; in practice, an agreed upon definition is impossible to give [13]. However, the concept of 'global civil society' is pervasive nowadays, while a few decennia ago the term had little or no currency [40]. If global civil society is something truly universal, how would judgments about its structure hold true across different geographical and cultural contexts?

As mentioned, clear definitions about the concept are often vague and difficult to register, but there is a universal consensus that global civil society evolves where the role of the state diminishes. It is a liquid phenomenon that fills the vacuum left by the withdrawal of the state. During the present neo-liberal era this is the case and the organisations that exist between the individual and the state become more influential.

Without clarity, civil society will intend to be a poor guide to public policy and citizen action, regardless of the posited goals [13]. In this sense, it is crucial to not look at civil society as a holy phenomenon that could deliver a utopian society, but to boldly look at reality.

The concept of global civil society has, when fully fulfilled, wonderful characteristics. The political pursuit of equality, transparency and accountability helps establish a new set of ethical norms taking into account the different circumstances around the world. The harsh reality is, however, that some parts of the world are more globalised than others. In the places with a high level of globalisation, global civil society is arguably more evident than in places which are less globalised. When asking a member of a tribe in the mountains of central India about the elements of a good society, the preferred answer is likely to differ from that from a Muslim living in Istanbul.

So, how do we determine whether or not a concept is truly global? A simple, but effective norm is: "Civil society becomes 'global' or 'international' only when it has some activity in more than one state" [41]. Due to the fact that civil society is not the product of one single nation-state or limited by borders, the concept can indeed be labelled as being global. Civil society moves in a number of directions and is presented differently in each country in which it operates. The nation-state is of vital importance for the civil society. While at the same time the fear of the replacement of government by civil society organisations is unnecessary. Global civil society will never become too powerful; just as concentrated power is contrary to democracy, it is not beneficial for civil society either.

The goal for states is to create a platform for people to make their voice heard, while for civil society the goal is to act according that voice. Nothing is worse than "if people feel exploited by the economic systems in which they work, ignored by the political systems in which they vote, and excluded by social systems that discriminate by race, gender or sexual orientation" [13] and 'exit' seems to be the best solution.

\section{Cross-cultural interaction}

As argued above, many developments in the globalisation process are causing world-wide changes in culture. However, does this mean that a unified world culture is emerging? Coca-Cola's famous 1970s advertisement in which children 
representing cultures from around the world were singing and, of course, drinking Coke symbolised the emergence of a 'global culture'. Some commentators even speak about cultural imperialism or 'McDonaldisation' [43,44]. This perspective is based, however, on the assumption that Western cultural elements are uncritically absorbed by non-Western nations and that cultural inflows are suppressing existing local meanings and forms [50].

A second theory refers to cultural differentiation or lasting difference. According to this view, the future will be characterised by a mosaic of immutably different cultures and civilisations [38]. Huntington [26] argues that world politics is entering a new phase and that the fundamental source of conflict in this new world order will be cultural. The increasing interaction between peoples of different civilisations will 'intensify civilisation consciousness and awareness of differences between civilisations and commonalities of civilisations'. That is, 'civilisation identity will be increasingly important in the future' and that the world will be shaped in large measure by the interactions among seven or eight major civilisations (i.e., cultural entities), which include Western, Confucian, Japanese, Islamic, Hindu, Slavic-Orthodox, Latin-American, and possibly African civilisation. However, Huntington's views have given rise to extensive debates and his argument has been widely rejected [38].

A third theory argues that local cultures are more robust and adaptive than the rhetoric of globalisation would have us believe: a well-established viewpoint among social-cultural scientists considers globalisation as a process of hybridisation that gives rise to a global mélange [38]. Cultural hybridisation or cultural mixing refers to processes of local absorption of cultural flows and the mixture between global and local cultural elements. Inflowing cultural elements, such as television series, Western consumer articles and values introduced by migrants, can become elements of the local daily life, often in changed forms and adapted to the local context [50]. Hannertz [20] argues, for example, that the local is the area 'where the global, or what has been local somewhere else, also has some chance of making itself at home'.

\section{Towards an understanding of the concept of globalisation}

In any discussion about globalisation very few of the debate's participants deny the existence of the phenomenon. It is widely accepted that we all live in a globalising world. The debates and protests emphasise how important it is to measure globalisation. Without doing so, it is impossible to assess the severity or benefits of its effects and how it should be managed - if, in fact, it can even be considered manageable. The winners and losers from structural changes that globalisation seem to accelerate are the prime political actors in the debates. As mentioned before, globalisation became a prominent topic from the early 1980s. Until that time, the topic was irregularly discussed. While deindustrialisation in developed economies has long been a concern, it is moot as to why the most recent wave of globalisation has been such a controversial issue.

Each perspective on globalisation emphasises different factors as the key elements behind the contemporary impact of the phenomenon. Moreover, they each presuppose a different definition of globalisation. In our opinion, rather than attempting to define globalisation and determine its effects by emphasising particular aspects or factors, it is far more useful to adopt a more multi-dimensional, pluralistic approach - including social-cultural elements next to the traditional focus on the economy. This will prevent an over-simplification of the complexities involved in understanding globalisation, while permitting a flexible definition of contemporary globalisation.

In order to be in a position to evaluate the consequences of globalisation, objective indicators, such as the Maastricht Globalisation Index (MGI) [35], developed by the Dutch research institute ICIS, Maastricht University, and the Index of Globalisation produced by the KOF Swiss Economic Institute [11] are extremely insightful.

To assess the extent to which any country is more (or less) globalised at any particular point in time requires much more than employing data on flows of trade or foreign direct investment. Both political integration and social integration are also important for a range of issues that affect social welfare. For example, in the absence of restrictions on capital mobility, a country is more likely to competitively lower taxes or offer subsidies to attract investment, the closer is a potential host country's culture to that of a source country and the easier it is to exchange information. Lower taxes may also lower the social safety net. On the other hand, political integration may ameliorate a potential 'race to the bottom', which may be induced by economic globalisation.

The MGI and KOF Index are founded on the idea that globalisation includes social, political as well as economic factors (and, in case of the MGI, ecological and technological factors as well). Specifically, globalisation is defined as the intensification of cross-national economic, political, cultural, social and technological interactions that lead to the establishment of transnational structures and the integration of economic, political and social processes on a global scale (see $[12,42])$.

A potential danger associated with indices of globalisation is that countries in the top ten of a globalisation index ranking are regarded as the most merit worthy. However, to evaluate the rankings, we need to consider what it means to be at the top, middle or bottom of a globalisation ranking. We provide such an evaluation in Measuring Globalisation - Gauging its Consequences [12]. For example, when the natural environment and the trade in conventional arms are included in these indices, as the MGI does, countries may be more globalised when their ecological footprint is high or when they are actively involved in arms trading. Not necessarily a good thing! On the other hand, most economists consider the average effect of globalisation on the economy to be positive. One of the virtues of indices of globalisation is that they provide a tool with which to empirically examine and discuss such widely held beliefs. However, as stressed above, other non-economic elements are equally important in the globalisation debate (see Box 1). 
Box 1. The social-cultural dimension in the MGI and KOF indices of globalisation

The MGI includes the following social and political indicators (in addition to the environmental and economic ones): Global politics: First among the indicators of political integration are the diplomatic relations that constitute an historical basis for communication between countries. It seems logical that the more important are the links to the outside world, then the more diplomatic links countries will establish to stay informed, protect their interests and facilitate communication. Since no aggregated statistics on diplomatic relations are available at a global level, the number of in-country embassies and high commissions are used. Membership in international organisations is a similar measure of the extensity of the international relations and involvement of a country. Moreover, since such memberships do not necessarily entail the need to maintain expensive representations abroad, this measure is less dependent on the size of the country.

Organised violence: This military indicator measures the involvement of a country's military-industrial complex with the rest of the world. While data quality is low, they nevertheless offer an insight into weapons proliferation, international military aid and the reasons and results of international peace-keeping operations. This dimension has not previously appeared in other globalisation indices. Of the quantitative military indicators proposed by [24], trade in conventional arms, compiled by the Stockholm International Peace Research Institute (SIPRI), is the only variable available for a reasonable number of countries.

People on the move: This measure encapsulates migration and the international linkages that come with the movement of populations between different countries. Newly arrived immigrants often maintain close connections to their home countries based on family ties and cultural similarities, often sending money home to their relatives and economic dependents.

Tourism brings people in contact with each other. It changes attitudes and promotes understanding between cultures that would otherwise have little contact. As a major economic activity, it can bring prosperity to regions with no other resources than the natural beauty of the surroundings or the cultural value of historic sites. Tourism has grown steadily in the last century, the major impetus being cheaper air travel. It represents an important part of globalisation and is therefore included in the index.

The KOF Index classifies social globalisation in three categories. The first covers personal contacts, the second includes data on information flows and the third measures cultural proximity.

Personal contacts: This index is intended to capture the direct interaction among people living in different countries. It includes international telecom traffic (outgoing traffic in minutes per subscriber), international letters sent and received and the degree of tourism (incoming and outgoing) a country's population is exposed to. Government and workers' transfers received and paid (as a percentage of GDP) measure whether and to what extent countries interact, while the stock of foreign population is included to capture existing interactions with people from other countries.

Information flows: While personal contact data are meant to capture measurable interactions among people from different countries, the sub-index on information flows is meant to measure the potential flow of ideas and images. It includes the number of internet hosts and users, cable television subscribers, number of radios (all per 1000 people) and the number of newspapers traded (per 1000 people). To some extent, all these variables proxy people's potential for receiving news from other countries - they thus contribute to the global spread of ideas.

Cultural proximity: Cultural proximity is arguably the dimension of globalisation most difficult to grasp. According to [46], cultural globalisation in large part refers to the domination of U.S. cultural products. Arguably, the United States is the trendsetter in much of the global socio-cultural realm [45]. As proxy for cultural proximity, the number of McDonald's restaurants located in a country is included. For many people, the global spread of McDonald's is synonymous with globalisation itself. The number of lkea outlets located in a country and trade in books and pamphlets are also included. Imported and exported books (relative to GDP) are used, as suggested by [30]. Traded books are intended to proxy the extent to which beliefs and values move across national borders. The number of lkea outlets per country is motivated in a similar fashion to the number of McDonald's restaurants.

With the introduction of the globalisation indices, a number of studies have empirically addressed the question of whether and to what extent globalisation affects social phenomena. Ekman [14] investigated whether globalisation affects the health of a country's population. Ekman finds a positive, non-linear correlation between the KOF Index and population health as measured by life expectancy at birth. In later studies, Sameti [47] finds that globalisation increases the size of governments, while Tsai [51] shows that globalisation increases human welfare, measured by the Human Development Index. Globalisation does not threaten either social solidarity or the welfare state [3]. In contrast, Koster [31] shows that welfare state effort is not affected by social globalisation, while the level of generosity is negatively affected. Bjørnskov [6] analyses the three dimensions of the KOF Index and shows that economic and social globalisation affect economic freedom, while political globalisation does not. Table 1 provides an overview of studies that have utilised the social dimension of the KOF Index to estimate impacts on a variety of factors.

\section{Labour within globalisation}

Let's consider one aspect closely related to globalisation in more detail, using development in Ghana as illustration [8]. At the fall of the Berlin, wall not only did neo-liberalists celebrate the end of history, they also commemorated the death of 
Table 1

Impacts of social globalisation.

\begin{tabular}{|c|c|c|}
\hline Study & Impact on... & \\
\hline \multirow{3}{*}{$\begin{array}{l}\text { C. Bjørnskov, Globalization and economic freedom: new evidence using the Dreher indices, } \\
\text { University of Aarhus, } 2006 \text {. }\end{array}$} & Legal quality & + (in autocracies) \\
\hline & Regulatory freedom & + \\
\hline & Access to sound money & + (in democracies) \\
\hline $\begin{array}{l}\text { A. Dreher, Does globalization affect growth? Evidence from a new index of globalization, } \\
\text { Appl. Econ., 38(10) (2006) 1091-110. }\end{array}$ & Economic growth & + \\
\hline \multirow{4}{*}{$\begin{array}{l}\text { A. Dreher, The influence of globalization on taxes and social policy-an empirical analysis for OECD } \\
\text { countries, Eur. J. Polit. Econ., 22(1) (2006) 179-201. }\end{array}$} & Government spending & 0 \\
\hline & Taxes on labour & 0 \\
\hline & Taxes on consumption & 0 \\
\hline & Taxes on capital & $+1-$ \\
\hline $\begin{array}{l}\text { A. Dreher, J.E Sturm, H.W. Ursprung, The impact of globalization on the composition of government expenditures. } \\
\text { Evidence from panel data, Public Choice, } 134(3-4)(2008) 263-92 .\end{array}$ & Composition of government expenditure & 0 \\
\hline R. Hattari, S.R. Ramkishen, Intra-Asian FDI flows: trends, patterns and determinants, 2006, mimeo. & Intra-Asian FDI flows & + \\
\hline S.W. Choi, Beyond neo-Kantianism: peace through globalization? University of Illinois at Chicago, 2007 mimeo. & Military disputes & 0 \\
\hline A. Dreher, N. Gaston, Has globalisation really had no effect unions? Kyklos 60(2) (2007) 165-86. & Union membership & - \\
\hline A. Dreher, N. Gaston, Has globalisation increased inequality? Rev. Inter. Econ. (2007). & Income and earnings equality & 0 \\
\hline W. Jacoby, EU enlargement: managing globalization by managing Central and Eastern Europe, 2007, mimeo. & EU Integration (catch up) & + \\
\hline \multirow{2}{*}{$\begin{array}{l}\text { F. Koster, Globalization, social structure, and the willingness to help others: a multilevel analysis across } 26 \\
\text { countries, Eur. Sociol. Rev., } 4 \text { (2007) 1-20. }\end{array}$} & Willingness to help the sick and disabled & 0 \\
\hline & Willingness to help immigrants & + \\
\hline \multirow{2}{*}{$\begin{array}{l}\text { F. Koster, The effects of social and political openness on the welfare state in } 18 \text { OECD countries, } \\
\text { Int. J. Soc. Welfare, (2007). }\end{array}$} & Welfare state effort & 0 (for 18 OECD-countries) \\
\hline & Level of generosity & - (for 18 OECD-countries) \\
\hline $\begin{array}{l}\text { N. Potrafke, Social expenditures as a political cue ball? OECD countries under examination, } \\
\text { Humboldt University, 2007, mimeo. }\end{array}$ & Social expenditures & 0 \\
\hline N. Potrafke, Public health expenditures in OECD countries: does policy matter? Humboldt University, 2007, mimeo. & Health expenditures & 0 \\
\hline $\begin{array}{l}\text { N. Potrafke, Political effects on the allocation of public expenditures: empirical evidence from OECD countries, } \\
\text { Humboldt University, 2007, mimeo. }\end{array}$ & Government expenditure shares & 0 \\
\hline \multirow[t]{3}{*}{ M.C. Tsai, Does globalization affect human well-being? Soc. Indic. Res., 81(1) (2007) 103-26. } & Human welfare & + \\
\hline & Government revenue (state power) & 0 \\
\hline & Government social spending & + \\
\hline $\begin{array}{l}\text { B. Torgler, Trust in international organizations: an empirical investigation focusing on the United Nations, } \\
\text { Rev. Inter. Org., 3(1) (2008) 65-93. }\end{array}$ & Trust in international organisations & - \\
\hline
\end{tabular}

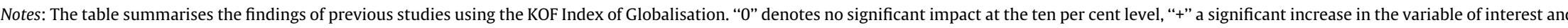
"_" a significant decrease in the variable of interest. 
work. Improvements in production and information technology had shortened spaces between countries almost rendering borders irrelevant [37]. The drivers of globalisation, computers and information technology, demanded minimal labour requirements in the form of highly trained computer experts. With time this assertion has proven to be untrue and globalisation's latest labour force, highly trained computer experts are yet to dominate production processes in developing countries like Ghana. Labour remains central to globalisation because the spread of capital is dictated by production and distribution of goods and services, artificial intelligence is yet to supply all the answers for human needs. Globalisation however has challenged the justification for labour to secure fair entitlements for its contribution to production.

Neo-liberal economic policy dictates that nation-states relinquish their role in production to the more efficient private capital, calling for a re-definition of labour's position within the production process. Consumer satisfaction directs the goals of national production for global consumption. Under what is generally termed Import Substitution Industrialization (ISI), which characterised national development policies in the 1960s and 1970s, the focus of development was national [39]. Countries such as Ghana, Kenya pursued development through industrialisation to feed domestic consumption [32]. Önder explains that under ISI national consumption was important to economic growth and workers income crucial in sustaining that consumption [39]. Globalisation replaced ISI with Export Oriented Growth and suppressed the interests of labour in favour of capital. Manda and Sen note how economic reforms in Kenya during the 1990s called for adjustments in labour laws that increased the vulnerability of the Kenyan labour force [32]. The immediate post-independence phase in Ghana is characterised as a labour friendly period. The Ghanaian state was engaged in direct production and industries enjoyed protection from external competition. Neo-liberal reforms soured the friendly state and labour movement relations [8].

When interrogating the position of the nation-state within globalisation writers have been concerned about the tendency of neo-liberal principles to undermine national sovereignty and citizenship entitlements [37,21]. Critics of the various economic packages that accompany financial support to ailing economies of developing countries like Ghana have expressed concern about the national ownership of IMF/World Bank economic programs and the tendency to submerge citizens' voices and welfare benefits in a bid to get market prices right [37]. Citizens who vote governments into power no longer constitute the centre of national policy-making neither are their inputs into economic planning guaranteed if they do in any way contradict the dictates of World Bank and IMF.

The implementation of neo-liberal economic policies depends on state power to curb citizens' rights in so far as they are incompatible with the profit making interests of transnational capital. Labour's fortunes within globalisation are undermined by an ideological discourse that upholds profits as a sign of efficiency that will generate the required levels of productivity to sustain economic growth for national development. To succumb to labour demands or interests will be to render an economy inefficient and directed towards failure. Thus, from a favoured position under production system that produces to satisfy national needs, labour now stands in the way of national progress if it insists that its interests should be considered.

\section{Future prospects}

Although we did not discuss all elements related to globalisation in the previous sections, globalisation increases economic growth, but also inequality. It is beneficial to the natural environment in the medium term, but harmful in the longer run [12]. Deunionisation increases as a consequence of globalisation. How to weigh, e.g., the positive impact of globalisation on economic growth against reduced deunionisation or increased inequality is not obvious and, clearly, the overall judgement depends on one's preferences and political inclinations. It also strongly depends how the process of globalisation unfolds in the years to come [33,25].

Looking at globalisation scenarios that explore the global and regional dynamics, we see a traditional distinction between classes of scenarios structured by defining them ex ante along two dimensions [34]. The first dimension relates to the extent both of economic convergence and of social and cultural interactions across regions; the second has to do with the balance between economic objectives and environmental and equity objectives. Beneath the diversity in scenario names and the narrative motivation for each storyline lies a common set of archetypal globalisation pathways: a globalising world with a market-oriented economic focus, a globalising world with a 'sustainability' focus and a fragmented world (i.e., a retreat of globalisation).

The first group of scenarios describes a globalising world with an economic focus. Globalisation develops rapidly within the materialist-consumerist paradigm. Under this scenario, social concerns and the quality of the environment are subsidiary to the principal objective: the development of economic prosperity. Underlying themes combine economic and cultural convergence as well as the development of economic capacity with a reduction in the difference between rich and poor, whereby regional differences in per capita income decrease in relative (but not necessarily absolute) terms. A variant of this scenario also envisages a future in which economic prosperity is the principal goal, but this prosperity is then expressed in a more heterogeneous world. Underlying themes include the reinforcement of regional identity with an emphasis on family values and local traditions, and strong population growth. Technological changes take place more slowly and in a more fragmented fashion than in the other scenarios. This is a world with greater diversity and more differences across regions.

In the second group, striving for economic prosperity is subordinate to the search for solutions to environmental and social problems (including problems of inequity). While the pursuit of global solutions results in a world characterised by increased globalisation and fast-changing economic structures, this is accompanied by the rapid introduction of clean 
technology and a shift away from materialism. There is a clear transformation towards a more service and information-based economy.

The third group depicts a world that advances local and regional solutions to social, economic and ecological problems. This is a heterogeneous world in which technological development is slower and more varied, and in which considerable emphasis is placed on initiatives and innovation from local communities. Due to higher than average levels of education and a considerable degree of organisation within communities, the pressure on natural systems is greatly reduced.

In most economists' reading, the average effect of globalisation on the economy appears to be positive in net terms. However, looking to future potential scenarios above, it is obvious that globalisation also may produce losers. This is hardly surprising, because globalisation affects the underlying structure of economies causing the shift of workers and other factors of production from industry to industry as well as from country to country. According to normative economic theory, the losers from these structural shifts should be compensated from the winners' gains. Of course, it is stating the obvious that they most often are not. This is one reason for the visible concern about globalisation. Transfers from the winners to the losers of globalisation are more difficult to implement in practice than in theory. First, the losers have to be identified. Second, they have to be compensated without producing adverse incentives to the economy as a whole. While there is now sufficient empirical evidence to at least tentatively conclude on the first of these issues, the second, more pressing, one remains as one of the most challenging research questions for social scientists.

\section{Conclusion: one world}

Apparently, we are not witnessing a returning to the era of the nation-state, but rather the rise of a new sort of government that regulates the process of globalisation and tries to improve the access of the powerless to global institutions. We move away from purely state-centred approaches, the same hold true of analyses at the personal level as well as the geographical level. Social relations change as a result of intensifying interconnectiveness. The present situation demands not only a new approach by the political power governing the state, but also by the inhabitants of that state. "Whereas the citizen is still trapped in the framework of the nation-state, the bourgeois acts in a cosmopolitan manner - which means that when his democratic hearts throbs, his action no longer has to obey the imperatives of national loyalty" [2].

The institutions of global civil society place limits upon the government and function as a sort of check towards various forms of government, especially the authoritarian and absolution varieties. "All governmental institutions, from local councils through territorial states and regional and supra-national institutions like the United Nations and the World Trade Organization, are now feeling the pinching effects of this civil society" [27]. Besides this monitoring role civil society also occupies itself with the distribution of socio-economic power within the global civil society. These functions of civil society overlap with some functions of the government and can be problematic. Some parts of society are highly organised and the decision making process facilitates institutions taking part within the civil society. Unfortunately, other parts of society are less transparent and have less access to government or international organisations operating within civil society.

These ideas of a loss of sovereignty by the nation-state due to the globalising process are perhaps best explained in the book Empire (2000) by Hardt and Negri [22]. They contend that globalisation does not mean the end of the nation-state, let alone the end of sovereignty. Nation-states are part of a bigger system, something what they call Empire. Empire is not bound to any borders and is a decentralised phenomenon. It is the way towards a new international order which can be labelled as a new transnational democracy. The role of the nation-state might seem to be diminishing; within Empire its role is still quite essential. "The nation-state serves various functions: political meditation with respect to the global hegemonic powers, bargaining with respect to the transnational corporations, and redistribution of income" [22]. States filter the processes which trickle from the top down, "in other words, they capture and distribute the flows of wealth to and from the global power, and they discipline their own populations as much as this is still possible" [22].

\section{Acknowledgements}

The authors thank the reviewers, as well as Lotte van Boxem, Akua Britwum and Maarten Bening for input that lead to improvements in this paper.

\section{References}

[1] M. Albrow, The Golden Age: State and Society Beyond Modernity, Polity, Cambridge, 1996.

[2] U. Beck, What is Globalisation? Polity, Cambridge, 2000.

[3] A. Bergh, Explaining Welfare State Survival: The Role of Economic Freedom and Globalization, Ratio Institute, Stockholm, 2006.

[4] J. Bhagwati, In Defense of Globalization, Oxford University Press, New York, 2004.

[5] M. Bilgin, On civilized plurality: mapping the clash of civilizations within the market, Futures 38 (2006) $247-260$.

[6] C. Bjørnskov, Globalization and Economic Freedom: New Evidence Using the Dreher Indices, University of Aarhus, 2006.

[7] P. Bourdieu, Acts of Resistance: Against the New Myths of Our Time, Polity Press, Cambridge, 1998.

[8] A.O. Britwum, P. Martens (2008). The challenge of globalization, labor market restructuring and union democracy in Ghana. Afr. Stud. Quart.,10, 2 \& 3: (Fall 2008) http://africa.ufl.edu/asq/v10/v10i2a1.htm.

[9] M. Castells, The Power of Identity. The Information Age: Economy, Society and Culture, Blackwell Publishing, Malden, 1997.

[10] N. Chomsky, World Orders Old and New, Columbia University Press, New York, 1994.

[11] A. Dreher, Does globalization affect growth? Evidence from a new index of globalization, Appl. Econ. 38 (10) (2006) $1091-1110$.

[12] A. Dreher, N. Gaston, P. Martens, Measuring Globalisation: Gauging its Consequences, Springer, New York, 2008. 
[13] M. Edwards, Civil Society, Polity Press, Cambridge, 2004.

[14] B. Ekman, Globalization and Health: An Empirical Analysis Using Panel Data, Lund University, Lund, 2003.

[15] R. Falk, The quest for humane governance in an era of globalization, in: D. Kalb, M. van der Land, R. Staring, B. van Steenbergen, N. Wilterdink (Eds.), The Ends of Globalization, Rowman \& Littlefield, Oxford, 2000, pp. 369-382.

[16] P.C. Fiss, P.M. Hirsch, The discourse of globalization: framing and sensemaking of an emerging concept, Am. Soc. Rev. 70 (2005) 29-52.

[17] Foreign Policy (with A.T. Kearney), Measuring globalisation: the global top 20, Foreign Policy, May-June (2005) 53-60.

[18] T.L. Friedman, The Lexus and the Olive Tree, Farrar, Strauss and Giroux, New York, 1999.

[19] N. Gaston, D. Nelson, Structural change and the labour market effects of globalisation, Rev. Int. Econ. 12 (2004) 769-792.

[20] U. Hannertz, Transnational Connections: Cultures, People, Places, Routledge, London, 1996.

[21] M. Harcourt, Neo-liberal reforms and accords: are they compatible with democracy? in: M. Harcourt, G. Wood (Eds.), Trade Unions and Democracy: Strategies and Perspectives, Manchester University Press, Manchester, 2004, pp. 40-61.

[22] M. Hardt, A. Negri, Empire, Harvard University Press, Cambridge, 2000.

[23] D. Harvey, The Condition of Modernity: An Enquiry into the Origins of Cultural Change, Basil Blackwell, Oxford, 1989.

[24] D. Held, A.G. McGrew, D. Goldblatt, J. Perraton, Global Transformations: Politics, Economics and Culture, Stanford University Press, Stanford, 1999.

[25] B.B. Hughes, P.D. Johnston, Sustainable futures: policies for global development, Futures 37 (2005) 813-831.

[26] S. Huntington, The clash of civilizations, Foreign Aff. Summer (1993) 22-49.

[27] J. Keane, Global Civil Society? Cambridge University Press, Cambridge, 2003.

[28] D. Kellner, Media Culture: Cultural Studies, Identity and Politics Between the Modern and the Postmodern, Routledge, London, 1995.

[29] R.O. Keohane, J.S. Nye, Introduction, in: J.S. Nye, J.D. Donahue (Eds.), Governance in a Globalizing World, Brookings Institution Press, Washington, DC, 2000 pp. 1-44.

[30] R. Kluver, W. Fu, The cultural globalization index, Foreign Policy online Web Exclusive, Available from: http://www.foreignpolicy.com/story/cms.php?story_ id=2494, 2004.

[31] F. Koster, Globalization, social structure, and the willingness to help others: a multilevel analysis across 26 countries, Eur. Sociol. Rev. 4 (2007) 1-20.

[32] D. Manda, K. Sen, The labour market effects of globalisation in Kenya, J. Int. Dev. 16 (1) (2004) $29-43$.

[33] P. Martens, J. Rotmans, Transitions in a globalising world, Futures (37) (2005) 1133-1144.

[34] P. Martens, J. Rotmans (Eds.), Transitions in a Globalising World, Swets \& Zeitlinger, Lisse, 2002.

[35] P. Martens, D. Zywietz, Rethinking globalisation: a modified globalisation index, J. Int. Dev. (18) (2006) 331-350.

[36] J.H. Mittleman, The Globalization Syndrome: Transformation and Resistance, Princeton University Press, Princeton, 2000.

[37] R. Munck, Globalisation and Labour: The New 'Great Transformation', Zed Books, London, 2002.

[38] J. Nederveen-Pieterse, Globalization and Culture, Rowman \& Littlefield Publishers, Inc., Lanham, 2004.

[39] N. Önder, Integrating with the global market: the state and the crisis of political representation, Int. J. Polit. Econ. 28 (2) (1998) $44-84$.

[40] R.B. Potter, Geographies of Development, second ed., Pearson Education Limited, Harlow, 2004.

[41] B. Rajagopal, International Law From Below; Development, Social Movements, and Third World Resistance, Cambridge University Press, Cambridge, 2003.

[42] W. Rennen, P. Martens, The globalisation timeline, Integr. Assess. 4 (3) (2003) 137-144.

[43] G. Ritzer, The McDonaldization of Society, Pine Forge Press, New York, 1993.

[44] G. Ritzer, The McDonaldization, Thesis, Sage, London, 1998.

[45] N.M. Rosendorf, Social and cultural globalization: concepts, history and America's role, in: J.S. Nye, J.D. Donahue (Eds.), Governance in a Globalizing World, Brookings Institution Press, Washington, DC, 2000.

[46] T. Saich, Globalization, governance, and the authoritarian state: China, in: J.S. Nye, J.D. Donahue (Eds.), Governance in a Globalizing World, Brookings Institution Press, Washington, DC, 2000

[47] M. Sameti, Globalization and Size of Government Economic Activities, Isfahan University, Isfahan, 2004.

[48] S. Sassen, Economic internationalization: the new migration in Japan and the United States, Int. Mig. 31 (1993) 73-102.

[49] J.A. Scholte, What is Globalization? The Definitional Issue - Again, CSGR Working Paper No. 109/02, Centre for the Study of Globalisation and Regionalisation, University of Warwick, Warwick, 2002.

[50] U. Schuerkens, The social and anthropological study of globalization and localization, Curr. Sociol. 51 (2003) 209-222.

[51] M.C. Tsai, Does globalization affect human well-being? Sociol. Indic. Res. 81 (1) (2007) 103-126.

[52] UNDP, Human Development Report 1999: Globalization With a Human Face, Oxford University Press, New York, 1999.

[53] M. Waters, Globalisation: Key Ideas, Routledge, London, 1995 